\title{
Aspects of the Construction of Housing and Settlement In Indonesia
}

\author{
Nina Karlina \\ Departement of Public Administration \\ Universitas Padjadjaran \\ Bandung, Indonesia \\ karlina_nina@yahoo.com
}

\begin{abstract}
Settlement development in both urban and rural areas in Indonesia is essentially to create the conditions of urban and rural to be livable, safe, comfortable, peaceful and prosperous and sustainable. Settlement is one of the basic human needs. The government is obliged to provide an access to the public to be able to obtain a settlement that is livable, prosperous, civilized and fair. Housing as one of the basic needs, up to now has been mostly provided independently by communities both to build their own or lease to another party. Regulations and legislation is a legal basis for the adoption of the various basic wisdoms and discretions in the administration and implementation of development field. Various legislations in the housing sector has been begun initiated and issued by the government, but it has not been able to provide a significant impact in the development of housing and settlement. This paper contains about how the construction of housing and settlement in West Bandung as seen from the aspect of policy.
\end{abstract}

Keywords-Policy, Housing, Settlement, West Bandung

\section{INTRODUCTION}

Housing problem in Indonesia stems from a shift in population concentrations from rural to urban areas. Urban population growth in Indonesia is quite high, around $4 \%$ per year, higher than the national growth, and are likely to continue to rise. It shows a high tendency growth of cities in Indonesia. Unfortunately, a state that does not match the level of ability with the human resource requirements for employment in urban areas, resulting in the emergence of social class economic level is very low. This resulted in the level of satisfaction of basic needs of the poor it can be said to be very minimal. Home and shelter they are no more a place to survive in the midst of city life. The quality of their settlements are considered low and does not meet the standards of living

The imbalance of supply and demand. Needs most is derived from the lower middle class homes, while there is a trend-party developers primarily private-public building for the upper middle promise greater profits. Sustainability (sustainability) and residential homes. There are no effective systems for evaluating the housing, in order to obtain an overview of community life in which post-occupancy. Though

\author{
Riki Satia Muharam \\ Departement of Public Administration \\ Universitas Muhammadiyah Bandung, STIA CIMAHI, \\ STIKEP PPNI Jawa Barat \\ Bandung, Indonesia \\ riki_satiamuharam@yahoo.co.id
}

it is important to improve the quality of housing in a sustainable manner.

The government's role in housing and settlement development is very important to control not to cause conflict settlement among development actors is oriented to the RTRW predetermined so that service delivery infrastructure and services do not create conflicts of interest.

Community involvement in housing and settlements relating to the function of management and control so that the house is not misused functioned as utilized in the non allocation. With the involvement of the home not only as a place to stay that is habitable, a means of fostering the family, but also can reflect the dignity of the residents as well as asset for the owner.

In terms of policy development of housing and residential areas, the main problem often faced is how the role of the government in terms of providing land and other facilities and infrastructure so as to allow the construction of housing and affordable housing for all segments of society, especially lowincome communities.

The development of an area can be realized, if supported by the availability of good infrastructure. The existence of infrastructure has a very important role in realizing the social interaction and the continuity of the economic system. The better the state of infrastructure, the greater the influence on social interaction and economic circumstances of a region and will spur progress and development of a region.

To carry out such construction, of course, required the development phases. Stages of development is first and foremost for infrastructure development is the availability of land. The availability of land needed spatial planning is mainly residential. Spatial Planning seems to be encouraged is the spatial plan in accordance with the principles of spatial planning based on community participation, especially in development settlement. With a community-based, the expected development of the region and the environment in an integrated manner. Planning the construction of settlements in 
the regional spatial planning proposals and suggestions regarding the provision of the applicable with legislative provisions and submitted either in writing or orally to the local government.

These issues would require constructive handling in the form of a comprehensive policy planning. The government have a role in settings, and control involving multi stkeholder. Policy and program development of housing and settlement should be made in the form of road map that from time to time adapted to the dynamics of change and development environment is rapidly increasing.

\section{LITERATURE}

\section{Concept of Public Policy}

The problems that arise and grow within a country is a matter to be considered by the government. That is because the state administration have function as a public service, where an administrator should be able to solve the problems that arise and grow as well as concerning the lives of many people. In other words, the state administration relating to the implementation of state policies. This is in accordance with the opinion expressed by referring to the opinion Pfiffner and Presthus, that the state administration is a process associated with the implementation of the policy (Handayaningrat, 1996: 3).

Here is the opinion of Miftah Thoha who explained that the subject of the first concern of the state administration is public policy.

"Administration of the country has dimensions as a field of study, and the first dimension is the" public policy ". Public policy is very important in the state administration as specified in the policy direction that should be taken in knowing the issues that developed in the community. In addition, the policy also used to determine the scope of the task to be done by the government and the people. "(Thoha, 1984: 51).

White expressed the opinion, that the state administration consists of all activities to achieve goals or to implement public policy (Thoha, 2002: 71).

Policy given meanings vary, for example, James E. Anderson in Irfan Islamy give meaning to the following policies :

"A purposive course of action followed by an actor or set of actors in dealing withn a problem or matter of cancern”. (Islamy, 2000:17)

Jenkins formulating state policy as :

"A set of interrelated decisions taken by a political actor or group of actors concerning the selection of goals and the means of achieving them within a specified situation where these decisions should in principle, be within the power of these actors to achieve."
Regarding the relationship between variables in the model of Van Meter and Van Horn, schematically model of Van Meter and Van Horn can be seen from the image below :

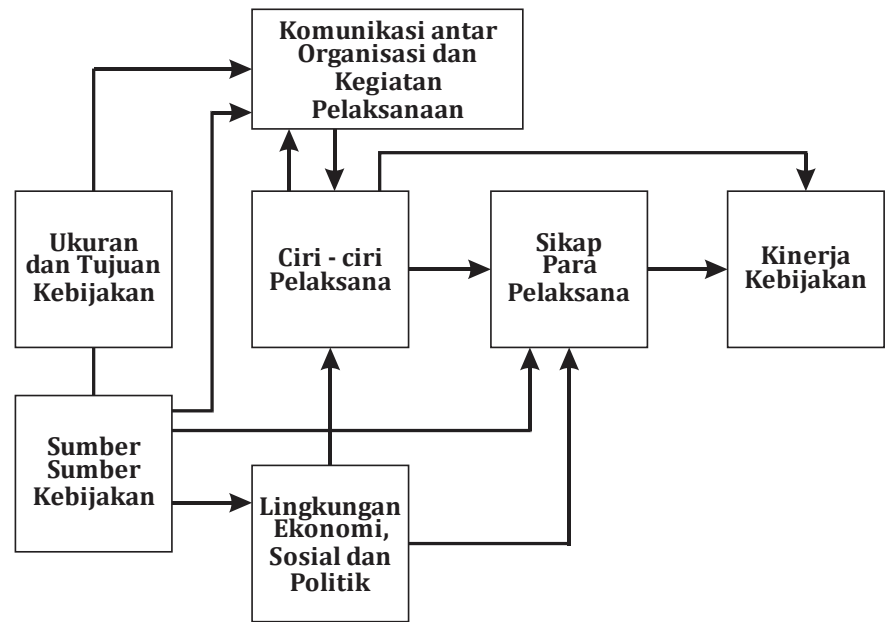

Picture 2. Model of Policy Implementation Process. Source : Van Meter dan Van Horn, The Implementation Process: A Conceptual Framework, Administration and Society (1975: page 445-448).

From these images revealed that there is a relationship of mutual influence between the variables or the main factor in the implementation of the policy. Eg resource factors or variables can affect the social, economic and political as well as affecting also the communication between implementers. Environment variable social, economic and political influence policy performance. Variable communication between the executing agency has a relationship with the interplay with the implementing agencies, and executive attitude.

\section{RESEARCH METHOD}

The object of research in this study is an analysis of the policy aspects of the construction of housing and settlement, in West Bandung, Indonesia. The study was conducted using a qualitative approach, using this approach, the authors delve more deeply about the real condition of the development policy of housing and residential areas in the district. West Bandung.

The data collection techniques are as follows :

1.In-depth interview. The author did with informants who are considered most knowledgeable about development policy of housing and residential areas in the district. West Bandung. 2. Field observations. Researchers conducted observations to find data and information on the development policy of housing and residential areas in the district. West Bandung. 3. Focus Group Discussion. FGD is done by involving all relevant stakeholders and regional development policies of housing settlements in the district. West Bandung. 4.The study of literature. The author did by examining the various theories related to the policy of housing construction and residential areas in the district. West Bandung.5.Secondary data 
collection related to the policy development of housing and residential areas in the district. West Bandung.

The data obtained will be tested by triangulation to all data sources that are considered related to the problems and research topics. Next will be presented in a systematic and clear description of the data and information obtained. The data were analyzed descriptively by mapping and describing aspects analyzed systematically.

\section{DISCUSSION}

A basic understanding of settlements in Act 1 of 2011 is part of a residential neighborhood consisting of more than one housing unit that has the infrastructure, facilities, public utilities, as well as having other functions area of activities supporting urban or rural areas. According Koestoer (1995) limits the settlements is closely linked to the concept of environment and spatial planning. Settlement is the area of land used for residential area or residential environment and the activities that support the livelihoods and are part of the environment outside the protected area, and includes urban and rural area.

Settlements in West Bandung regency is still dominated by the non-settlement, settlement developed by the community on an individual basis, while housing managed by a developer or a formal housing is starting to develop in West Bandung.

Housing and settlements in addition to being one of the basic human needs, also has a highly strategic function in its role as the center of family education, nursery culture, and improving the quality of future generations, as well as a manifestation of identity. The realization of the people's welfare can be characterized by increasing the quality of a decent and dignified life, including through the fulfillment of the boards. An attempt to put the housing and settlement as one of the priority sectors in the whole of Indonesian human development is very strategic.

Settlement in each region will continue to grow, in line with population growth and the growing activity in the region. Under these conditions requires the development of the area of land into smaller plots non woke up, one of which the settlement developed as a residence. Most of the development of settlements in a region dominated by the self-help housing developed by the community, but there are also housing developed by the developer. Several areas in West Bandung regency already emerging formal housing projects with varying house types, the type of house large, medium and small.

Population pressure on the land is one of the problems for natural resources and the environment. West Bandung district has a population of 1,531,072 inhabitants with an area of $1311.31 \mathrm{~km}^{2}$. One of the problems posed is a deviation determining the location of housing. Location of housing other than eligible to the physical, should also consider the feasibility of economically and ecologically. The phenomenon of the increasing deviation of location for housing some consequences for the government to adopt a sustainable supply and housing construction. The housings should have geological and topographical conditions that can guarantee the security of the settlements. Apart from having to have this level of robustness and high stability should also have a low degree of slope (the maximum is $15 \%$ ), not under the local water table.

The population in West Bandung regency from year to year tend to grow and land is certainly not changed, this causes overcrowding to occupy an increasingly crowded field. The largest population contained in Lembang district in the amount of 182.487 people, while the population of the lowest in the District Saguling ie 29.108 inhabitants. Most of the population $(73 \%)$ had lived in the district that includes urban areas in West Bandung regency. Districts with the highest density found in the District Ngamprah by 45 inhabitants / ha, there are districts with the lowest density in the District Gununghalu by 4 people / ha. While the overall density in West Bandung regency is 12 inhabitants / ha.

Number of poor in urban areas as many as 527.908 people or $49 \%$ of the total urban population. While number of poor people in rural areas as much as 270.853 people or $63 \%$ of the total rural population. The number of slums in urban areas based on the location of as many as 244 locations, while in rural areas as many as 37 locations. For a number of families in urban areas as much $22.757 \mathrm{KK}$ or $96 \%$ of the total districts, whereas in rural areas as many as 1,040 households, or $4 \%$ of the total district.

The problem of housing and residential district. West Bandung is inseparable from the dynamics that occur in the life of society and of government policy in managing housing and settlement. In West Bandung regency related to the policy development of housing and residential areas based on Law No. 1 Year 2011 on on Housing and Region Settlements, Regulation West Java Governor Number 46 Year 2015 on Guidelines Program Home Improvement Not Livable, and Local Regulations relating to Spatial, and improving the quality of coaching implementation of the settlement, by facilitating the preparation and utilization SPPIP and RPKPP as a reference for building settlements in the district. West Bandung.

\section{RUTILAHU}

West Java Governor Regulation No. 46 Year 2015 on Guidelines for Home Improvement Program Not Livable, there is mentioned that the house is not habitable, hereinafter referred Rutilahu are homes that do not meet the safety requirements of the building and the building area minimum requirement and the health of its inhabitants. Programs and activities of the house is not habitable for Low-Income Communities and Families includes Rutilahu Urban Poor and Rural Rutilahu. Rutilahu repair must meet the program's 
criteria and the criteria for targeting aid. Beneficiary selection criteria include: an Indonesian citizen, married, owner rutilahu is the poor who are in the Central Bureau of Statistics, the prospective beneficiaries directly own and control the land inhabited by sufficient evidence of ownership, potential beneficiaries had not received help repair homes from another program, either from the State budget, Provincial Budgets, Budgets District / Municipal and private, are willing to participate and labor costs during the implementation of the rehabilitation and reporting, and is willing to maintain the results of the rehabilitation of the house with no provision resell. Criteria for targeting aid includes: roofs made of materials such as thatch, zinc, thatch, roofed, roof tiles, damaged, floor of the house is still in the form of land, board bamboo, cement in a damaged condition, the walls of houses are still made of bamboo / sesek, booths, board, bark, or a wall in a damaged condition, have no window / ventilation or window / ventilation air in damaged condition, and do not have latrines or toilets in a damaged condition.

Table 1

Number of houses according properties and material in West Bandung Regency

\begin{tabular}{|c|c|c|c|c|c|c|c|c|}
\hline \multirow[b]{2}{*}{ No } & \multirow[b]{2}{*}{ Districs } & \multicolumn{6}{|c|}{ The Nature of Houses According House (Unit) } & \multirow[b]{2}{*}{ Amount } \\
\hline & & Permanent & $\begin{array}{c}\text { Semi- } \\
\text { Permanent }\end{array}$ & $\begin{array}{l}\text { Wood/ } \\
\text { Board }\end{array}$ & $\begin{array}{l}\text { Other } \\
\text { Bambu }\end{array}$ & Stage & $\begin{array}{c}\text { Not } \\
\text { Liveable }\end{array}$ & \\
\hline 3 & Batujajar & 16,238 & 4,402 & 238 & 12 & 198 & 225 & 21,313 \\
\hline 4 & Cisarua & 4,056 & 3,397 & 1,841 & 1,900 & 1,471 & 2,497 & 15,162 \\
\hline 5 & Lembang & 2,215 & 6,650 & 3,483 & 1,108 & 1,262 & 2,241 & 46,959 \\
\hline 6 & Parongpong & 20,322 & 6,003 & 494 & 962 & 424 & 1,009 & 29,214 \\
\hline 7 & Cililin & 9,641 & 5,051 & 1,934 & 1,053 & 5,688 & 4,311 & 27,678 \\
\hline 8 & Cihampel & 31 & 5 & 2,866 & 3,764 & 51 & 279 & 30,346 \\
\hline 9 & Cikalongwetar & 346 & 3,560 & 2,367 & 1,596 & 5,025 & 3,392 & 28,286 \\
\hline 10 & Cipeundeuy & 9,447 & 1,971 & 2,124 & 1,560 & 4,086 & 4,234 & 23,422 \\
\hline \multicolumn{2}{|c|}{$\begin{array}{l}\text { Sub-Total Urban } \\
\text { Area }\end{array}$} & 163,640 & 48,590 & 16,445 & 13,543 & 19,606 & 21,222 & 283,046 \\
\hline \multicolumn{9}{|c|}{ Rurals Region } \\
\hline 1 & Rongga & 1,924 & 1,084 & 1,46 & 0 & 13,080 & 2,103 & 19,658 \\
\hline 2 & Gununghal & & & 4,3 & 2,58 & 6,4 & 3 & 22,017 \\
\hline 3 & Sindangkerta & 5,493 & 1,1 & 301 & 293 & 10,214 & 1,895 & 19,386 \\
\hline 4 & Cipongkor & & & 11,815 & 20 & 0 & 0 & 22,544 \\
\hline 5 & Saguling & 2,54 & 2,28 & 904 & 10 & 2,009 & 1,099 & 8,939 \\
\hline 6 & Cipatat & 16, & 6, & 2,165 & 4,984 & 91 & 0 & 30,056 \\
\hline \multicolumn{2}{|c|}{$\begin{array}{l}\text { Sub-Total Rurals } \\
\text { Area }\end{array}$} & 4774 & 18,823 & 20,998 & 7,971 & 31,875 & 8,459 & 122,600 \\
\hline \multicolumn{2}{|c|}{ Tota District } & 198,114 & 67,413 & 37,443 & 21,514 & 51,481 & 29,681 & 405,646 \\
\hline
\end{tabular}

Source : Adapted from Database Development, BAPPEDA, 2016.

The budget for the program repair uninhabitable housing (rutilahu) in West Bandung Rp 10 billion for the program in 2016. Budget rutilahu sourced from the budget allocated for 2000 units rutilahu throughout West Bandung regency. This program provides assistance to people who are less capable. Each unit houses get help Rp 5 million, rutilahu program's implementation is assisted by assisting consultants. Distribution of the budget channeled directly from DPPKAD (Department of Revenue, Finance and Asset Management) West Bandung regency to beneficiaries as a data CPCL (Receiver Candidates and Candidate) through the chairman of KSM (Self-Help Groups). Data are eligible to receive the existing recommendation from the village, to the help of the provincial government is channeled through the Community Empowerment Board and village authorities. Based on existing data, 29,000 rutilahu which were recorded, 17,000 of whom have received rutilahu program and for 2016 the number rutilahu there are still about 12,000 housing units. Of that amount, rutilahu itself most in the southern region of West Bandung regency.

A total of 41 houses unfit to live in RW 12, Desa Suntenjaya, Lembang district, West Bandung Regency has been repaired by non-governmental sources of funding. This is a pilot project for improvement rutilahu in a number of other villages in the district Lembang initiated Muspika Communication Forum Leaders districts. This program started running since October 2015. With funding non-governmental, private assisted government agencies from program P2WKSS West Bandung District Government, rutilahu improvements can be completed. Rutilahu improvement funds come from benefactors origin Lembang and government and private agencies. Besides given to homeowners, rutilahu funds were also submitted to the local committee or collected in the district first and then submitted to the building committee, development committee RW prioritize spending level of material and worker wages and drive the mutual aid society. In addition to building houses, Lembang district government is also building three latrines distributed in RW 12, Desa Suntenjaya. As for the lighting needs, submitted to the West Bandung regency through the Rural Electricity Program. Repair rutilahu with governmental help accelerate the development, because in Lembang, rutilahu number reached 2,200 units. With these programs, rutilahu repairs can be completed.

The benefits of development programs rutilahu've felt a lot of those in need, this program is helping people's lives, especially in terms of health, home which had no window and ventilation, very stuffy, after receiving the (aid) rutilahu, in each room there is a window, the room is more spacious, good for health.

Deviations space utilization is indicated by the high conversion of productive land due to the influence of economic activity, population growth and socio-cultural conditions. The transformation that occurs generally ignore the spatial plan that has been planned in advance. Putting land into cultivation area of protected areas (developed and undeveloped land) is still relatively high.

The development of the productive land conversion for industrial investment activities, services and settlements that are not in line with the pattern of planning a predetermined impact in the form of environmental damage, decrease in support of the environment and threaten food security. The land conversion is an indication of the vulnerability of the land that is the cause of environmental degradation. This is among other things due to the non-functioning control aspects in the implementation of spatial planning, as well as related to the licensing authority and the space utilization is still often carried out as part of the target revenue (PAD).

The problem is generally the housing and settlement in the district. West Bandung that existed at the moment is not yet solid service and access to land rights for housing, especially 
for the poor and low income. The capacity of the district government. West Bandung is still relatively limited in order to implement effectively the implementation of adequate land administration, which can ensure adequate supply of land, which can develop the land market in an efficient and sustainable land use. The high demand for affordable housing and still be partly offset because of the limited ability of the provision by the public, business and government. The inability of the poor and low income to obtain adequate housing and affordable and that meet neighborhoods responsive (healthy, safe, harmonious, and sustainable).

Functionally, the majority of the quality of housing and settlements are limited and do not meet the standards of adequate services appropriate scale defined area, both as a residential area as well as a sustainable settlement area. Physically environtment, still found many residential areas and settlements already exceed capacity and environmental capacity, facing the impact of its association with the scale of the wider region, as well as its integration problems with the system infrastructure and facilities in both urban and rural areas.

Implementation of housing and settlement based on community involvement as the main actors should be institutionalized continues at the local community level and was supported effectively. Various product policy settings in the administration of housing and settlements should be able to support efforts to increase the role of communities and businesses, and local government in accordance with the demands of regional autonomy.

\section{CONCLUSION}

West Bandung regency $(\mathrm{KBB})$ has a hilly geographical conditions with varied height and slope. Housing and settlements in addition to being one of the basic human needs, also has a highly strategic function in its role as the center of family education, nursery culture, and improving the quality of future generations, as well as a manifestation of identity.

The problem of housing and residential district. West Bandung is inseparable from the dynamics that occur in the life of society and of government policy in managing housing and settlement. Implementation of housing and settlement based on community involvement as the main actors should be institutionalized continues at the local community level and was supported effectively. Various product policy settings in the administration of housing and settlements should be able to support efforts to increase the role of communities and businesses, and local government in accordance with the demands of regional autonomy.

\section{REFERENCES}

[1] Brown, Lisanne; Lafound Anne; Macintyre, Kate, 2001, Measuring Capacity Building, Carolina Population centre/University of North Carolina, Chapel Hill

[2] Dunn, W. 2000. Pengantar Analisis Kebijakan Publik. Yogyakarta : Gadjah Mada University Press, Jogjakarta

[3] Handayaningrat, Soewarno. 1996. Pengantar Studi Ilmu Administrasi dan Manajemen. Jakarta: CV. Masagung.

[4] Islamy, M. Irfan. 2004. Prinsip-Prinsip Perumusan Kebijakan Negara. Jakarta : Bumi Aksara.

[5] Keban, Yeremias T. 2004. Enam Dimensi Strategis Administrasi Publik Konsep, Teori dan Isu. Yogyakarta: Gava Media.

[6] Morrison, Terrence, 2001, Actoinable Learning - A Handbook for Capacity Building Through Case Based Learning. ADB Institute

[7] Patton, C. V. dan David S. Sawicki. 1986. Basic Methods of Policy Analysis \& Planning. Publishers : Pearson.

[8] Rusli, Budiman. 2013. Kebijakan Publik, membangun pelayanan publik yang responsive. Bandung : Hakim Publishing.

[9] R. Dye, Thomas. (1987). Understanding Public Policy. United States of America. Prentice-Hall.

[10] Shafritz, J.M., \& E.W. Russel. 1997. Introducing Public Administration. New York: Addison-Wesley Educational Publisher.

[11] Solichin, Abdul W. 2002. Analisis Kebijaksanaan : Dari Formulasi ke Implementasi Kebijaksanaan Negara. Jakarta: Bumi Aksara.

[12] Tangkilisan, Hessel Nogi S., 2005. Kebijakan dan Manajemen Otonomi Daerah. Yogyakarta: Lukman Offset Yogyakarta.

[13] Thoha, Miftah. 2002. Dimensi-dimensi Prima Ilmu Administrasi Negara. Jakarta : Raja Grafindo Persada.

[14] Umar, Husein. 2004. Metode Riset Ilmu Administrasi. Jakarta : PT Gramedia Pustaka Utama.

[15] Wahab, Solichin Abdul. 1997. Analisis Kebijakan Publik; Dari Formulasi ke Implementasi Kebijakan Negara. Jakarta. PT Bumi Aksara.

[16] Winarno, Budi. 2002. Teori dan Proses Kebijakan Publik. Yogyakarta : Media Pressindo.

[17] Yuwono, Teguh, 2003, "Capacity Building and Local Government : Concept and Analysis”, Makalah pada seminar Internasional Democracy and Local Politics diselenggarakan oleh PSSAT UGM, STPMD “APMD, UAJY, Yogyakarta, 7-8 Januari.

Document :

[18] Law of the Republic of Indonesia Number 1 Year 2011 concerning the Housing and Settlement Region

[19] West Java Governor Regulation No. 46 Year 2015 on Guidelines for Home Improvement Program Not Livable

[20] Regional Long Term Development Plan (RPJPD) District. West Bandung.

[21] Medium Term Development Plan (RPJMD) District. West Bandung. 